\title{
O. KONONENKO
}

\section{THEORETICAL ASPECTS OF THE ORGANIZATION BRAND MANAGEMENT}

The subject matter of research in the article is the development of the concept of "brand", as well as modern approaches to the process of brand formation of the organization. Recent decades the concept of "brand" has become widespread. It is applied to the individual, to the enterprise, and also to government initiatives. However, in the literature there is no single point of view on the definition of this concept. The goal of the article is to analyze the existing definitions of the concept of "brand" and modern approaches to the process of brand formation of the organization. To achieve this goal, it is necessary to solve the following tasks: to collect the definitions of the concept of a brand, given by organizations, scientists, specialists, to analyze these definitions and their dynamics, to analyze the main features of strategic brand management. The system analysis method was applied to achieve the goal of the work. Results. The most well-known definitions of the concept of "brand" are given. It is shown that it can be considered from the standpoint of a company that creates goods or provides services under its own brand, or from the standpoint of a buyer who perceives this brand. The way this concept evolves over time is analyzed. It is shown that the brands are a combination of tangible and intangible elements that can be combined into the following groups: visual design elements, distinctive product features (quality, individuality, sounds, aroma, taste, etc.), intangible aspects of customer interaction with the product or company. quality of customer service, etc.). Based on the analysis of existing concepts, the own definition of the concept of "brand" is proposed, which meets the requirements of modernity. The definition of "branding" is considered. It is shown that brand management uses a variety of marketing tools and techniques to increase the value of branded goods in the eyes of buyers and that a large proportion of buyers are willing to pay more for the product of your favorite brand. The main stages of strategic brand management include: determining the position and value of the brand, planning and implementation of the brand marketing program, measuring brand effectiveness, increasing and maintaining brand value. The concept of "brand book" and the advantages of its use are considered. The structure of the brand book is described. It is shown that it is important for the development of companies to create a marketing strategy for rebranding. In the process of rebranding, there are usually four main stages, namely: marketing audit, brand repositioning, restyling of its visual attributes and changing the principles of communication. Conclusions: the definition of "brand" and the use of strategic brand management and rebranding will form the brand of the organization, which will be better perceived by consumers and will have a positive image in society.

Keywords: brand; definition; branding; brand book; rebranding; stages.

\section{Introduction}

In the modern world, it is difficult to find a person who would never use the word "brand" or did not have even the slightest idea about its content, because at this stage of human development, this term permeates almost all aspects of society. Today, the term "brand" can be just as easily applied to a utility, charity, football team, badminton team, celebrity, or in general - to a government initiative, as previously applied exclusively to wrap in branded material packaging [1].

In general, the word "brand" comes from the Old Norse "brand", which translates as "smoke, fire", and the origins of its history can be found in the days when pastoralists burned certain characteristic symbols on the skin of cattle in order to then be able to distinguish animals that belonged to different owners [2]. Thus, even in ancient times, the "brand" was perceived as a distinctive feature that helped to distinguish the product or property of a particular owner from hundreds of other, outwardly very similar products.

However, still, despite the limitless scope of the concept of "brand" and its rich history, even in the specialized literature on branding it is impossible to find a single definition of this term.

\section{Analysis of recent research and publications}

The definition of "brand" in recent years has been devoted to the works of such authors as S. Ahmad, L. De Chernatony, R. Clifton, D. D'Alessandro, F.-R. Esch, J. Gregory, K. Keller, Ph. Kotler, M. Owens,
J. Wiechmann, A.W. Bulanov, E.A. Rudaya, D.A. Shevchenko and others. These definitions, on the one hand, differ significantly from each other, on the other hand, undergo changes over time. Definitions of this concept are closely related to the processes of forming a competitive brand of the organization.

\section{Purpose of the work}

The aim of the article is to analyze the existing definitions of the concept of "brand" and modern approaches to the process of brand formation of the organization. To achieve this goal it is necessary to perform the following tasks: to collect definitions of the concept of brand, which are given by organizations, scientists, specialists, to analyze these definitions and their dynamics, to analyze the main features of strategic brand management.

\section{Research results}

The essence of the brand and its main components.

The American Marketing Association defines "brand" as "a name, term, mark, symbol, design, or combination thereof, intended to identify the goods or services of one seller or group of sellers, and to distinguish a product or service from goods or services of competitors" [3].

ISO 10668: 2010 [4] defines a "brand" as an intangible asset related to marketing, including, but not limited to, names, terms, signs, symbols, logos and designs, or a combination thereof, designed to identify 
goods, services or organizations, or a combination of them, which creates different images and associations in the minds of stakeholders, thereby generating economic benefits/values.

Many scholars and practitioners in the field of branding, studying the question of how to correctly interpret such a fundamental concept as "brand", tried to provide their own options for its definition. The most well-known of them are listed below in table 1 .

Which of the proposed brand definitions is the most complete and meaningful? Which researcher's approach allows to identify the fundamental features of the concept of "brand" at a deep level? The answer to these questions is very difficult to provide, because the difficulty of unambiguous interpretation of the brand is due to a number of reasons. First, the brand, like any other complex phenomenon in marketing, is multifaceted. It can be viewed from the standpoint of a company that creates goods or provides services under its own brand, or from the standpoint of a buyer who perceives this brand. The desired image of the brand that the organization would like to get and its perception by customers in reality does not always coincide. Thus, the choice of different aspects and points of view provides a multifaceted interpretation of the concept of "brand". Secondly, it is necessary to distinguish between specific and abstract definitions of the brand, because much depends on the level of specification and the context of application of this concept. Third, the very concept of "brand" is constantly evolving under the influence of changes in the external marketing environment and, as a consequence, is filled with new meaning [13]. This is to meet the demands of consumers, which are changing, including as a result of gaining experience related to the product or service, as well as to constantly maintain and increase competitiveness $[14,15]$.

Table 1. Approaches to defining the concept of "brand" of different researchers

\begin{tabular}{|c|c|}
\hline Definition & Researcher \\
\hline $\begin{array}{l}\text { A brand is not a thing, a product, a company or an organization. } \\
\text { Brands do not exist in the real world - they are mental constructions. A } \\
\text { brand is best described as the sum of a person's entire experience, his } \\
\text { perception of a thing, product, company or organization. Brands exist } \\
\text { in the form of consciousness or specific people or society. }\end{array}$ & $\begin{array}{l}\text { James R. Gregory, from the book "Leveraging the } \\
\text { Corporate Brand" [5] }\end{array}$ \\
\hline $\begin{array}{l}\text { We define a brand as a trademark that in the eyes of the consumer } \\
\text { absorbs a clear and meaningful set of values and attributes. The } \\
\text { products are made in the factory. But a product becomes a brand only } \\
\text { when it acquires many tangible, intangible and psychological factors. } \\
\text { The main thing to remember is that brands are not created by the } \\
\text { manufacturer. They exist only in the minds of consumers. }\end{array}$ & $\begin{array}{l}\text { Charles Brymer, General Manager "Interbrand } \\
\text { Schecter" [6] }\end{array}$ \\
\hline $\begin{array}{l}\text { A brand is more than just advertising or even marketing. This is all } \\
\text { that comes to a person's mind about a product when they see its logo or } \\
\text { hear the name. }\end{array}$ & $\begin{array}{l}\text { David F. D'Alessandro, General Manager "John } \\
\text { Hancock", from the book "Brand Warfare: } 10 \text { Rules for } \\
\text { Building the Killer Brand" [7] }\end{array}$ \\
\hline A brand is a set of perceptions in the consumer's imagination. & $\begin{array}{l}\text { Paul Feldwick, Executive Director of Strategic } \\
\text { Planning, BMP DDB, International Director of } \\
\text { Branding Planning, DDB [6] }\end{array}$ \\
\hline $\begin{array}{l}\text { A brand is an identified product, service, person or place created in } \\
\text { such a way that the consumer or buyer perceives the unique added } \\
\text { value that best meets his needs. }\end{array}$ & $\begin{array}{l}\text { Leslie De Chernatony, Professor of Brand Marketing } \\
\text { and Director of the Center for Research in Brand } \\
\text { Marketing at Birmingham University Business School, } \\
\text { author of several books on branding [8] }\end{array}$ \\
\hline $\begin{array}{l}\text { Brands are figurative representations stored in the memory of } \\
\text { stakeholders, which perform the functions of identification and } \\
\text { differentiation and determine the behavior of consumers in choosing } \\
\text { products and services. }\end{array}$ & $\begin{array}{l}\text { Franz-Rudolf Esch, Professor of Marketing, University } \\
\text { of Giessen, Germany, Director of the Institute for Brand } \\
\text { and Communication Research ("Institut für Marken- } \\
\text { und Kommunikationsforschung") [9] }\end{array}$ \\
\hline $\begin{array}{l}\text { Brand is a name that influences the behavior of market consumers / } \\
\text { buyers. }\end{array}$ & $\begin{array}{l}\text { Jean-Noel Kapferer, Professor of the School of } \\
\text { Management HEC (France), recognized specialist in } \\
\text { branding [6] }\end{array}$ \\
\hline $\begin{array}{l}\text { A brand is a commercially valuable sign or sum of signs that is known } \\
\text { to a certain group of people, evokes in their memory similar } \\
\text { information and a similar attitude to real or imaginary objects } \\
\text { (interpretation). The brand is able to influence the behavior of this } \\
\text { group of people in the interests of its owner, which creates its } \\
\text { commercial value. The commercial value of a brand is also determined } \\
\text { by how easily it can be detached from one object and transferred to } \\
\text { another object or group of objects while maintaining its interpretation. }\end{array}$ & $\begin{array}{l}\text { A.V. Bulanov, from the book "Brand 2.0. From } \\
\text { philosophy to practice" [10] }\end{array}$ \\
\hline $\begin{array}{l}\text { Brand is a sign, symbol, word or combination thereof that helps } \\
\text { consumers distinguishing the goods or services of one company from } \\
\text { another. The brand is perceived as a well-known brand or company } \\
\text { that occupies a special place in the minds and psychology of consumer } \\
\text { segments from the masses of their own kind. }\end{array}$ & $\begin{array}{l}\text { D.A. Shevchenko, from the book "Advertising. } \\
\text { Marketing. PR" [11] }\end{array}$ \\
\hline $\begin{array}{l}\text { A brand is a receptive sign of an organization and its products, by } \\
\text { which the consumer can distinguish the organization and its products } \\
\text { from others. }\end{array}$ & $\begin{array}{l}\text { Chovanová, H. H., Korshunov, A. I., \& Babčanová, D. } \\
\text { [12] }\end{array}$ \\
\hline
\end{tabular}


Leading brand management specialist Leslie de Cernaton in his book "From brand vision to brand evaluation. Strategic process of brand growth and strengthening" identified and summarized the main approaches that interpret the brand [16]. We have displayed his achievements in the form of a diagram (fig. 1).

Obviously, a concept "brand" evolves together with development of world economy, for this reason already a long ago from a simple method for distinguishing of commodities of different producers a brand grew into the difficult, complex phenomenon that includes for itself quite a bit constituents and carries in itself deep maintenance. It is worth noting that even Philip Kotler has revised his own definition of the brand several times, constantly expanding its value. Thus, first, the founder of modern marketing management theory defined a brand as a name, term, trademark, symbol, image, or a combination thereof, designed to identify the goods and services of one seller or sellers and differentiate them from the goods and services of competitors. However, a little later F. Kotler clarified his previous definition: "A brand is any name, title, trademark, etc., which have a certain meaning and associations" [18]. Finally, Kotler's interpretation of the brand was transformed into: "Brand is a complex concept that can express six meanings: 1) attributes; 2) benefits; 3 ) value; 4) culture; 5) individuality; 6) user." [19].

Basic approaches that interpret the brand

From the company's position:

- identification system

- risk reduction tool

- brand contract

-added value

Fig. 1. Varieties of brand interpretations

The above definitions of the brand, proposed by Philip Kotler, actually lead us to the conclusion of what elements make up the brand - it contains all possible characteristics that distinguish goods and services from one seller to another: name, design, style, symbols, points interactions with customers, etc., and in general all elements of the brand work as a psychological trigger or stimulus that evokes an association with all other thoughts about the brand. Thus, brands are a combination of tangible and intangible elements that can be combined into such groups:

1) Visual design elements: name, logo, corporate colors and fonts, slogan, packaging, graphics, shape, etc.

2) Distinctive features of the product: quality, individuality, sounds (unique melody or set of notes can become a characteristic feature of the brand), aroma, taste, etc.

3) Intangible aspects of customer interaction with the product or company: reputation, quality of customer service, etc. [20].

Thus, the brand can be defined as a holistic image, which gradually develops in the minds of the target audience, based on all the information received, which relates to all aspects of the brand owner.

Modern approaches to the process of forming a competitive brand of the organization.

Creating a brand, despite the objective complexity of this task, is only the beginning of another infinitely long process called brand management, because for a brand to continue to succeed, companies must constantly make concerted efforts to ensure its dynamic branding.

In 2001, Molly Hislop defined branding as the process of establishing a connection between a company's product and its emotional perception by customers in order to differentiate itself from competitors and build loyal relationships with customers [21]. In 2004 and 2008, Kapferer and Keller, respectively, published their vision of branding, in their view: "Branding is meeting customers' expectations and constantly meeting their needs" [22].

According to [23], brand management is the process of maintaining and improving a brand so that its name is associated with positive results. A brand is what customers think of when they see or hear a brand name, ie a brand is the image and individuality of a product or service offered by a company. Brand management, in turn, uses a variety of marketing tools and techniques to increase the value of branded goods in the eyes of customers. Based on the goals set by the marketing strategy, brand management allows product prices to grow and create loyal customers through positive associations and images, or good awareness of potential consumers about the brand. For example, Scott Davis published a study in his book, which indicates that $72 \%$ of buyers are willing to pay a price for a favorite brand that is $20 \%$ higher than the price of the nearest competing brand; $50 \%$ of buyers are ready for a similar excess of the price by a quarter, and $40 \%$ are even willing to overpay 
a third of the price in order to buy a product of a certain brand [24].

Thus, proper brand management can increase loyalty to it, which in turn forces customers to return, which in turn directly affects the company's benefits. Simply said, a successful brand allows its rights holders to raise product prices and increase their own profits. In fact, without smart brand management, most global companies would not have achieved such success.

The authors of [25] conducted a survey of consumers and concluded that brand knowledge has a great influence on consumer behavior, and this result is statistically significant. Brand knowledge includes brand awareness and brand image. People are switching from local to branded products. They like to use branded products to show their status, power and wealth.

In [26], based on a survey of 200 graduates and working young people, it was concluded that there is a strong statistically significant positive correlation between advertising and brand preferences, as well as the relationship between customer income and brand preference.

The process of strategic brand management is necessary to create and maintain brand value. Developing a strategy that successfully maintains or improves brand awareness, strengthens consumer associations with it, emphasizes the quality and usefulness of the brand, is an important task of brand management. In general, in the process of strategic brand management, researchers identify the following main stages:

1. Determining the position and value of the brand.

The first step in the strategic brand management process begins with a clear definition of what a brand should be in terms of value to consumers, and how it should be positioned in a competitive market. Philip Kotler notes that brand positioning is a set of actions of the company to form its offer and build an image so that the brand occupies a special and significant place in the minds of the target consumer.

2. Planning and implementation of a brand marketing program.

Brand building is the next step in managing an organization's brand. This stage of forming a holistic brand involves planning such components as pricing, packaging, customer service and more. In addition, during this stage, techniques are developed to build a recognizable brand and further support consumer awareness of it, i.e. at this stage; strategies for marketing, branding and advertising are agreed.

3. Measuring brand effectiveness.

It is important not only to create a brand, but also to constantly measure and monitor its effectiveness against competitors and other market dynamics. There are several different theories as to which parameters best reflect the effectiveness of a brand. Let's focus on the list proposed by $D$. Aaker, which includes such indicators as: brand awareness, perceived quality / brand leadership, brand loyalty, brand associations and indicators of market behavior (e.g., market share) [27].

4. Increasing and maintaining brand value.
The final stage in the process of brand management after evaluating the effectiveness is to work on improving the brand image to ensure the growth and maintenance of brand value. Brand value is a measure of the quality it offers [28].

In general, according to a study by Lucidpress, consistent and continuous branding can increase the company's average annual profits by about $23 \%$, but despite these statistics, only a quarter of organizations have their own official brand book (or brand style guide) whose recommendations they really follow. In fact, about $60 \%$ of companies admit that the product they create does not always meet the principles of their brand [29]. Although it is consistent adherence to the developed principles that helps companies achieve the coherence needed to form a recognizable brand, positive associations and, as a result, gain customer loyalty.

A brand book or brand style guide is an official document that sets out specific guidelines for maintaining brand identity in all external and internal communications. Brand books often contain clear recommendations on the correct use of the logo, corporate colors, acceptable manipulation of images and photos, information about the voice/tone of the brand ("Tone of voice"), etc.

The most obvious advantage of having, and most importantly - the constant use of a brand book, is that it provides an organization that works under its own brand, consistency and unity, which help to form the identity of the brand image. All this over a longer period contributes to the emergence of trust and loyalty from the target audience.

A brand book is usually created according to a certain structure and consists of three main sections: "About the brand", "Recommendations for visual content", "Principles of communication".

The section "About the brand" prescribes the mission, values and target audience of the brand. Identifying these points at the outset is a key to further creating a logical and holistic image.

In the section "Recommendations for visual filling" you need to provide all the necessary information about the following elements:

1) Logo: its location, variations for different platforms and channels, colors, sizes and proportions;

2) Corporate colors: color palette and texture, necessarily their monochrome version;

3 ) Fonts: corporate typography, which is used in the titles and main texts of official documents;

4) Photos: their style and basic principles, accompanied by specific examples;

5) Other: brand names, patterns, graphics, icons,

The final section "Principles of communication" describes in detail the principles of communication between the brand and its target audience, they include:

1) Language: official-business, informal;

2) Tone: authoritative, caring, conservative, friendly, provocative, humorous, etc.;

3) Style: formatting, use of terminology, admissibility of slang and its limits, branded "emoji";

4) Presence in social networks: types of publications, time of publications, different styles of social media; 
5) E-mails: structure, signature and tone;

6) Readability and grammar: types of sentences and their length, capital letters, numbers, abbreviations, abbreviations [30].

Thus, it can be argued that the brand is a well-thought-out system of associations that identify it in the eyes of consumers, and the brand book helps the company to adhere to the chosen concept and consolidate the image of the brand in the market. However, sometimes companies no longer want or can maintain a stable image, and they need to make changes to brand positioning, separate from the negative nuances of previous branding, broadcast a new philosophy of the organization, expand or change their target audience, or transfer the company to higher level. To solve such problems, there is a marketing strategy of rebranding, which creates a new name, logo, slogan, design, concept or combination for the existing brand in order to form a new, differentiated identity in the minds of consumers, investors, competitors and other stakeholders' parties [31]. This often involves radical changes in brand image, marketing strategy and advertising topics.

In the process of rebranding, there are usually four main stages, namely: marketing audit, brand repositioning, restyling of its visual attributes and changing the principles of communication. Let's consider in more detail what measures each of the specified stages provides.

Marketing audit. The main goal is to assess brand awareness and loyalty to consumers, study the images and associations it evokes in the target audience, and identify the strengths and weaknesses of the brand, its competitive advantages, and the presence of barriers to its positive perception. Based on the results of the marketing audit, a decision is made as to whether there is a need to reposition the brand.

The main task of brand repositioning is a significant change in the perception of the target market of its key advantages and features against the background of other proposals in a competitive market [32].

Restyling is a change in the design and visual attributes of a brand (logo, corporate identity, colors, etc.), i.e. it is a cosmetic change in its appearance. The task of transforming the ideology or positioning of the brand is not related to restyling, but the design change is in accordance with the previously developed new characteristics of the brand.
Changing the principles of communication involves the use of a new style of communication with the audience (changing the tone of messages, communication channels, etc.) to convey information about the updated characteristics of the brand [33].

\section{Conclusions}

The paper shows that the existing definitions of "brand" differ significantly from each other. The reasons for the differences are that this concept can be considered both from the standpoint of the company and from the standpoint of the buyer, the level of specification or abstraction may also differ. In recent years, there have been transformations of this concept from name, term, trademark, symbol, image or their combination to a complex concept that reflects the elements of visual design, product features, and intangible aspects of customer interaction with the product or company. Based on the analysis of existing concepts, the own definition of the concept of "brand" is proposed, which meets the requirements of modernity.

The definition of "branding" is given. It is shown that brand management uses a variety of marketing tools and techniques to increase the value of branded goods in the eyes of buyers and that a large proportion of buyers are willing to pay more for the product of your favorite brand. The main stages of strategic brand management include: determining the position and value of the brand, planning and implementation of the brand marketing program, measuring brand effectiveness, increasing and maintaining brand value.

The concept of "brand book" and the advantages of its use are considered. The structure of the brand book is described. It is substantiated why it is important for the development of companies to create a marketing strategy for rebranding. There are four main stages of the rebranding process, namely: marketing audit, brand repositioning, restyling of its visual attributes and changing the principles of communication. It is shown that the above definition of "brand" and the use of strategic brand management and rebranding will form the brand of the organization, which will be better perceived by consumers and will have a positive image in society.

The results of the work will be used in conducting a marketing audit of the existing brand of the organization providing educational services, and, if necessary, in developing proposals for its rebranding.

\section{References}

1. Clifton, R., Ahmad, S. (2009), Brands and Branding, John Wiley \& Sons, 256 p.

2. Keller, K. L. (2008), Strategic Brand Management, Pearson/Prentice Hall, 3rd edition.

3. "Branding", available at: https://www.ama.org/topics/branding/ (last accessed 20.02.2021).

4. "ISO 10668:2010 Brand valuation - Requirements for monetary brand valuation".

5. Gregory, J. R., Wiechmann, J. G. (1997), Leveraging the Corporate Brand, McGraw-Hill, 1st ed., 1997.

6. "Brand" ["Brend"] available at: http://www.neoanalytics.ru/media/file/binary/2011/7/4/201078651243/brend_pdf.pdf?srv=app1 (last accessed 20.02.2021).

7. D'Alessandro, D. F., Owens, M. (2001), Brand Warfare: 10 Rules for Building the Killer Brand, McGraw-Hill, 1 st ed., 204 p.

8. de Chernatony, L. (1998), Brand Management (The International Library of Management), Dartmouth Pub Co, 1 st ed.

9. Esch, F.-R. (1990), Expertensystem zur Beurteilung von Anzeigenwerbung, Physica-Verlag, 1st ed. 
10. Bulanov, A. V. (2014), Brand 2.0. From philosophy to practice [Brend 2.0. Ot filosofii k praktike], OJSC "Krasnaya Zvezda", Moscow, $496 \mathrm{p}$.

11. Shevchenko, D. A. (2014), Advertising. Marketing. PR [Reklama. Marketing. PR] : textbook, "RGGU", Moscow, 3rd ed., rev. and add, $639 \mathrm{p}$.

12. Chovanová, H. H., Korshunov, A. I., Babčanová, D. (2015). "Impact of brand on consumer behavior", Procedia Economics and Finance, No. 34, P. 615-621.

13. Rudaya, E. A. (2006), Fundamentals of Brand Management [Osnovyi brend-menedzhmenta], Aspect-Press, Moscow, 254 p.

14. Domnin, V. N., Starov, S. A. (2017), "Evolution of key concepts of brand management", Vestnik of Saint Petersburg University. Management, Vol. 16, Issue 1, P. 5-32. DOI: 10.21638/11701/spbu08.2017.101

15. De Chernatony, L., Drury, S., Segal-Horn, S. (2004), "Identifying and sustaining services brands' values", Journal of Marketing Communications, No. 10 (2), P. 73-93.

16. Chernatony, L. (2006), From Brand Vision to Brand Valuation. Strategic process of growth and strengthening of brands [Ot videniya brenda $k$ otsenke brenda. Strategicheskiy protsess rosta i usileniya brendov], Trans. from Eng., New knowledge, Minsk.

17. Kotler, P. (2005), Marketing of the XXI century [Marketing XXI veka], Trans. from English, Neva, Neva Economics, St. Petersburg, $425 \mathrm{p}$.

18. Kotler, P. (2007), Fundamentals of Marketing. Short course. [Osnovyi marketinga. Kratkiy kurs], Trans. from English, 8th ed., Williams, Moscow, $832 \mathrm{p}$.

19. Tretyak, O. L. (2005), Marketing: New Landmarks of the Management Model [Marketing: novyie orientiryi modeli upravleniya] : A Textbook, INFRA-M, Moscow, XII, 403 p.

20. "Elements of Brand. Principles of Marketing - Reading", available at: https://courses.lumenlearning.com/clintonmarketing/chapter/reading-elements-of-brand/ (last accessed 20.02.2021).

21. Hislop, M. (2001), Dynamic Logic 's Branding 101 : An Overview of Branding and Brand Measurement for Online, 22 p.

22. Shamoon, S, Saiqa Tehseen. (2011), "Brand Management: What Next?", Interdisciplinary Journal of Contemporary Research in Business, Business Source Complete. Web. Oct 20, 2012, No. 2.12, P. 435-441.

23. Gibson, K. (2009), "BusinessDictionary.com", Reference Reviews, $\quad$ Vol. $23 \quad$ No. 2, P. 25-26. DOI: https://doi.org/10.1108/09504120910935183

24. Davis, S. M. (2000), Brand Asset Management : Driving Profitable Growth through Your Brands, Jossey-Bass a Wiley Company, San Francisco.

25. Fatima, S., Aftab, M., Iqbal, M. T. (2014), "The impact of branding on consumer buying behavior", International Journal of Technology and Research, No. 2 (2), P. 54-64.

26. Lekshmi, D. N., Jeevandas, M. S. (2020), "Impact of Branding In Consumer Buying Behaviour and Influence of Advertisement on Branding", International Journal of Advanced Science and Technology, No. 29 (7), P. 4460-4465.

27. Aaker, D. A. (2003), Creating strong brands [Sozdanie silnyih brendov], Publishing house "Grebennikov", Moscow, 433 p.

28. "Brand Management Definition, Importance \& Example, Marketing Dictionary", available at : https://www.mbaskool.com/business-concepts/marketing-and-strategy-terms/10533-brand-management.html (last accessed 20.02.2021).

29. "How to Build a Brand Around Sustainability?", Lucidpress, available at : https://www.lucidpress.com/blog/how-to-build-brandaround-sustainability (last accessed 20.02.2021).

30. "How To Create A Brand Book", DesignRush, available at : https://www.designrush.com/trends/brand-book (last accessed 20.02.2021).

31. Muzellec, L., Lambkin, M. (2006), "Corporate rebranding: destroying, transferring or creating brand equity?", European Journal of Marketing, Vol. 40, No. 7/8, P. 803-824. DOI: https://doi.org/10.1108/03090560610670007

32. Lamb, C. W., Hair, J. F., McDaniel, C. (2009), Essentials of Marketing, South-Western.

33. Restyling. Marketer's notese [Restayling. Zapiski marketologa], available at : http://www.marketch.ru/marketing_dictionary/marketing_terms_r/restyling/ (last accessed 20.02.2021).

Received 27.02.2021

\section{Відомості про авторів / Сведения об авторах / About the Authors}

Кононенко Оксана Ігорівна - Харківський національний економічний університет імені Семена Кузнеця, студентка кафедри маркетингу, Харків, Україна; email: oksanako3101@gmail.com; ORCID: https://orcid.org/0000-0001-6919-0656.

Кононенко Оксана Игоревна - Харьковский национальный экономический университет имени Семёна Кузнеца, студентка кафедры маркетинга, Харьков, Украина.

Kononenko Oksana - Simon Kuznets Kharkiv National University of Economics, Student of the Department of Marketing, Kharkiv, Ukraine.

\section{ТЕОРЕТИЧНІ АСПЕКТИ УПРАВЛІННЯ БРЕНДОМ ОРГАНІЗАЦЇ̈}

Предметом дослідження в статті є розвиток поняття "бренд", а також сучасні підходи до процесу формування бренду організації. Поняття "бренд" в останні десятиліття набуло широкого поширення. Його застосовують і до окремої особистості, і до підприємства, і до державних ініціатив. Однак в літературі немає єдиної точки зору з приводу визначення цього поняття. Метою роботи $\epsilon$ аналіз існуючих визначень поняття "бренд" і сучасних підходів до процесу формування бренду організації. Для досягнення цієї мети необхідно виконати наступні завдання: зібрати визначення поняття бренд, які дані організаціями, науковцями, фахівцями, проаналізувати ці визначення та їх динаміку, проаналізувати основні особливості стратегічного управління брендом. Для досягнення мети роботи застосований метод системного аналізу. Результати. Наведено найбільш 
відомі визначення поняття "бренд". Показано, що його можна розглядати з позиції компанії, що створює товари чи надає послуги під власним брендом, або ж з позиції покупця, який сприймає цей бренд. Проаналізовано, як еволюціонує це поняття 3 часом. Показано, що бренди являють собою поєднання матеріальних та нематеріальних елементів, які можна поєднати у такі групи: елементи візуального дизайну, відмінні особливості продукту (якість, індивідуальність, звуки, аромат, смак тощо), нематеріальні аспекти взаємодії клієнтів з продуктом чи компанією (репутація, якість обслуговування клієнтів тощо). На основі аналізу існуючих понять запропоновано власне визначення поняття "бренд", яке відповідає вимогам сучасності. Розглянуто визначення поняття "брендинг". Показано, що бренд-менеджмент використовує розмаїття маркетингових інструментів та технік для збільшення цінності брендованого товару в очах покупців і що велика частка покупців готова більше заплатити за товар улюбленої марки. Основні етапи стратегічного управління брендом включають: визначення позиції та цінності бренду, планування та імплементація програми маркетингу бренду, вимірювання ефективності бренду, збільшення та підтримання цінності бренду. Розглянуто поняття "брендбук" та переваги його використання. Описано структуру брендбуку. Показано, що важливим для розвитку компаній є створення маркетингової стратегії ребрендингу. У процесі ребрендингу зазвичай виділяють чотири основні етапи, а саме: маркетинговий аудит, репозиціювання бренду, рестайлінг його візуальних атрибутів та зміна принципів комунікації. Висновки: наведене визначення поняття "бренд" і використання стратегічного управління брендом та ребрендингу дозволять формувати бренд організації, який буде краще сприйматися споживачами та матиме позитивний імідж у суспільстві.

Ключові слова: бренд; визначення; брендинг; брендбук; ребрендинг; етапи.

\section{ТЕОРЕТИЧЕСКИЕ АСПЕКТЫ УПРАВЛЕНИЯ БРЕНДОМ ОРГАНИЗАЦИИ}

Предметом исследования в статье является развитие понятия "бренд", а также современные подходы к процессу формирования бренда организации. Понятие "бренд" в последние десятилетия получило широкое распространение. Его применяют и к отдельной личности, и к предприятию, и к государственным инициатив. Однако в литературе нет единой точки зрения по поводу определения этого понятия. Целью работы является анализ существующих определений понятия "бренд" и современных подходов к процессу формирования бренда организации. Для достижения этой цели необходимо решить следующие задачи: собрать определения понятия бренд, данные организациями, учеными, специалистами, проанализировать эти определения и их динамику, проанализировать основные особенности стратегического управления брендом. Для достижения цели работы применен метод системного анализа. Результаты. Приведены наиболее известные определения понятия "бренд". Показано, что его можно рассматривать с позиции компании, создает товары или предоставляет услуги под собственным брендом, или с позиции покупателя, который воспринимает этот бренд. Проанализировано, как эволюционирует это понятие со временем. Показано, что бренды представляют собой сочетание материальных и нематериальных элементов, которые можно объединить в следующие группы: элементы визуального дизайна, отличительные особенности продукта (качество, индивидуальность, звуки, аромат, вкус и т.п.), нематериальные аспекты взаимодействия клиентов с продуктом или компанией (репутация, качество обслуживания клиентов и т.п.). На основе анализа существующих понятий предложено собственное определение понятия "бренд", которое отвечает требованиям современности. Рассмотрены определения понятия "брендинг". Показано, что бренд-менеджмент использует разнообразие маркетинговых инструментов и техник для увеличения ценности брендированного товара в глазах покупателей и большая часть покупателей готова больше заплатить за товар любимой марки. Основные этапы стратегического управления брендом включают: определение позиции и ценности бренда, планирование и имплементация программы маркетинга бренда, измерения эффективности бренда, увеличение и поддержание ценности бренда. Рассмотрено понятие "брендбук" и преимущества его использования. Описана структура брендбука. Показано, что важным для развития компаний является создание маркетинговой стратегии ребрендингу. В процессе ребрендинга обычно выделяют четыре основных этапа, а именно: маркетинговый аудит, репозиционирование бренда, рестайлинг его визуальных атрибутов и изменение принципов коммуникации. Выводы: приведенное определение понятия "бренд" и использование стратегического управления брендом и ребрендингу позволят формировать бренд организации, который будет лучше восприниматься потребителями и иметь положительный имидж в обществе.

Ключевые слова: бренд; определения; брендинг; брендбук; ребрендинг; этапы.

\section{Бібліографічні описи / Bibliographic descriptions}

Кононенко О. I. Теоретичні аспекти управління брендом організації. Сучасний стан наукових досліджень та технологій в промисловості. 2021. № 1 (15). С. 76-82. DOI: https://doi.org/10.30837/ITSSI.2021.15.076

Kononenko, O. (2021), "Theoretical aspects of the organization brand management", Innovative Technologies and Scientific Solutions for Industries, No. 1 (15), P. 76-82. DOI: https://doi.org/10.30837/ITSSI.2021.15.076 